\title{
Situational Analysis of Identification Graphics and Canopies in Tampico Downtown and Pedestrian Effect
}

\author{
R. I. Lozano-Castro ${ }^{1}$, J. Gonzalez-Velez ${ }^{2}$, M. T. Sánchez-Medrano ${ }^{2}$, L. A. Brandt-García ${ }^{3}$, \\ C. E. Berumen-Rodríguez ${ }^{1}$, K. Suarez-Dominguez ${ }^{3, *}$ \\ ${ }^{1}$ CADCP - FADU, Autonomous University of Tamaulipas, Circuito Universitario S/N CP89000, Tampico, Mexico \\ ${ }^{2}$ CADES- FADU, Autonomous University of Tamaulipas, Circuito Universitario S/N CP89000, Tampico, Mexico \\ ${ }^{3}$ FADU Research Centre, Autonomous University of Tamaulipas, Circuito Universitario S/N CP89000, Tampico, Mexico
}

Received July 7, 2021; Revised November 8, 2021; Accepted December 13, 2021

\section{Cite This Paper in the following Citation Styles}

(a): [1] R. I. Lozano-Castro, J. Gonzalez-Velez, M. T. Sánchez-Medrano, L. A. Brandt-García, C. E. Berumen-Rodríguez, K. Suarez-Dominguez, "Situational Analysis of Identification Graphics and Canopies in Tampico Downtown and Pedestrian Effect," Civil Engineering and Architecture, Vol. 10, No. 1, pp. 246-252, 2022. DOI: 10.13189/cea.2022.100121.

(b): R. I. Lozano-Castro, J. Gonzalez-Velez, M. T. Sánchez-Medrano, L. A. Brandt-García, C. E. Berumen-Rodríguez, K. Suarez-Dominguez (2022). Situational Analysis of Identification Graphics and Canopies in Tampico Downtown and Pedestrian Effect. Civil Engineering and Architecture, 10(1), 246-252. DOI: 10.13189/cea.2022.100121.

Copyright $\bigcirc 2022$ by authors, all rights reserved. Authors agree that this article remains permanently open access under the terms of the Creative Commons Attribution License 4.0 International License

\begin{abstract}
Tampico is an important commercial city at Tamaulipas, Mexico, founded in 1810, which has grown to occupy more than $70 \%$ of its habitable zone. The old town, for example, has buildings dating from the late nineteenth century to, mid-twentieth century belonging to the time of the Porfiriato (1876-1911) and the oil boom (1911-1938) that were modified in their use with the process of modernization. Currently, this sector is commercially distinguished. Every company that owns a building uses specific iconographic elements for graphics identification to make itself known. The exposed identification graphic is located in a space that can capture the pedestrian viewer's attention until its commercial and competitive identification to acquire the merchandise. In this sense, a study of 10 blocks of neighboring areas in the downtown city was carried out to recognize the current changes in derivatives of distinctive elements and the emerging need to increase the segment assigned in the step pedestrian, even when the inscription or graphic communication in the commercial identification graphics attracts the passing spectator's attention. On the other hand, special care has not been taken to maintain and preserve the architectural character of the historical area, detecting serious pathologies caused in the study due to a short intervention of the facades where the iconographic elements have been arranged.
\end{abstract}

Keywords Visual Street, Pedestrian in Downtown, Graphic Design and Facades

\section{Introduction}

Tampico has national importance, mainly due to its economic impact with the negotiation, for example, of 1,465 million dollars during 2013 [1] and being positioned as a growth zone in the production of hydrocarbons [2]. The city has grown over the years [3], with no logical buildings insertion into individual spaces [4]. However, there is an absence in the depth of analysis on this aspect in the old town of Tampico.

In this transition of the urban modernization process, the buildings have been arranged with the accompaniment of cultural-communicational design objects called identification graphics [5]. Graphical information has been a part of the history of buildings since the nineteenth and mid-twentieth century. The frontispiece [6] is considered an independent element enhancing ornamentation, identifying messages, or inscriptions. These inscriptions have been related to writing models that architects used to designate a distinction with name, year, symbol, for example, to distinguish it as an attribute 
of property. According to Bourdieu [7], the distinction signified a certain frequent quality of bearing and manners and the relational property that existed due to relationships with other properties.

In this regard, findings are derived from the research on commercial identification graphics on the facades of buildings in Tampico (1994-2013) [5]. They can be categorically considered as tradition, modernization, resistance, transculturation, and hegemony, to mention a few, which could be part of a reflective analysis considering the current state of the canopies. However, in other facades of a historical nature, a record of 104 identifying graphics was considered in the historical sector of the city [8]; they represent a determining aspect for the consideration of the identifying reserved space as its restoration and cultural permanence.

However, these identifying graphics were considered the most commercial objective for passersby spectator identification over time.

Pedestrian lifestyle is an essential factor in services given by companies and goods acquisition.

According to Lynch [9], an integrated scenario with a clear image is proposed that performs a social function with symbolic-historical-communicative-significant, integrated, and inclusive materiality that demonstrates a visual harmony represented with positive, legible values, comfort in its experience, and quality of life. In this regard, it is possible to generate a visual object identified by its structural and material usability, and that is architecturally integrated into the reading of the urban landscape. In this case, it is essential to denote de necessity of considering all the information exposed before in the impact of pedestrians and people who transport by walking in the Tampico Downtown, where various buildings with iconographic representations are found.

\section{Methods}

The exploratory research work was carried out through a flexible design with findings derived from a mixed, qualitative-semi-quantitative methodology, with descriptions, comparisons, and interpretations of the data obtained and complex data quantifiable. The information collected was presented deductively and inductively. The construction of a historiographic fabric was built with graphic-architectural identity results that represent the society of Tampico, Tamaulipas-leading to understanding the graphic production (with shapes, fonts, colors, and symbolism) visual memory of the city. In a deductive way, it is considered the link between the images of graphic identity with its production.

The type of research was semi-quantitative. Applying ethnography analysis with non-participant observation in the field, we identified a visual record of 10 blocks located in the Historic Center of the city of Tampico.

It was selected routes for identifying graphic objects and compositional elements derived from the historic building.

Within these tours, the prevailing pathologies were identified in the units that support the graphic objects. Carrying out a photographic survey and integrating information on injuries developed in canopies due to humidity concentration due to lack of downspouts. The visual image of the first painting of the city is the bad appearance that it causes to the visitor, pedestrian, or tourist; secondly, the potential danger of collapse due to the accumulation of harmful elements on the canopies.

The temporality considered in this research with the canopies and the identifying graphic objects considered whole was developed from February to June 2020. The geographical position was the first square of the historical sector covering five blocks indicated in red in Figure 1. 




Figure 1. First stage of research (red). Further research will be made for the others blocks.

\section{Results and Discussion}

The identifying graphics were representations in time and space that resulted from economic, political, technological, and cultural moments in the society of Tampico. We found no commercial graphic materialization, presenting ruptures and continuities in the urban image.

Similarities and differences were found in graphic productions: dimensionality characteristics, materiality (fashionable materials related to the time), informative-communicational content, irregular implementation in their placement.

Indeed, the city of Tampico has been the focus of public and commercial design with globalization and visual memory built with alternation in parallel. Precisely, the absence of accurate and significant communicative value in commercial graphic readability on public roads was noted: "The identifying design object built the culture, just as a culture built the identifying design object".

The disparity between the old town growth and urban planning caused accentuations in architectural materials, structural models, or supports. Types of printing, standardized formats, and regularized locations of commercial identifiers are also found. That generated that occasionally only the luminous advertisement or commercial identifying graphic was updated without considering the built structure that supports it. In some old households, the history of graphic identification is also presented in the upper frontispiece, i.e. year of construction, names or ornamentation. The commercial identification graphic is located in the lower part for identifying competition.

However, there is a gap between the planned historical graphic materiality and the contemporary (superimposed or placed) in the canopies. This resulted in the planning of the building, since the historical identification graphics; they have been considered part of the social collective with its distinction, as an elite code, link to lifestyle or social status. It is a reference of historical value, between other aspects; leaving away the merely commercial aspect for exchanging goods. These presented their inclusion and integration through the considered space and construction materials (such as stone, brick, cement, concrete, etc.) with writing models represented in high and low relief sculptures with inscriptions of graphic messages.

Contemporary identification graphics are intentionally commercial for social reception. Currently, they were placed superimposed on canopies that protrude from the bottom of historic buildings, or newly created buildings.

In some cases, we found printed with technology (structure and materials with light, technical means digital 
such as: 3D acrylic with led lighting; 3D translucent canvas with colored vinyl, interior light and foil on the edges; Trovisel laminate or mirror-finished aluminum, among others). Only in some cases, such as those of multinationals, they considered part of the corporate architecture. In other words, the journey form in its exposed communication was transformed by naming or imposing the title on the building as a commercial distinction [10]. The canopies identification graphics articulated production, circulation, and recognition relations based on identifying graphical statements, which were used and practiced based on their knowledge, recognition, social memorization, differentiation, association, and value as symbols of ideological empathy inclusion. Figure 2 shows the case of this use to promote sidewalk use and commercial place promotion.

According to the visible results of three-month follow-up, people using sidewalks reduced from an average of 128 people per hour to 35 , during business hours, at those streets that presented problems with canopies. However, people move toward other streets for walk-transport.

The best places with facades rehabilitation and graphic elements increase people walking on these streets by $55 \%$, showing that it is necessary to incorporate public strategies with a graphical design that genuinely protects the social subject quality of life, the urban landscape, and the Tampico and Mexican identity. Those responsible for urban aesthetics and functionality, such as the State and professionals of built materialism (architect and graphic designer), must generate a conciliation and inclusive planning that leads to materialized harmony for the inhabitants' quality of life. In addition to the State's commitment to implementing road signs or signage and billboards in public spaces, they impact the quality of life and the country's productive and commercial development. Figure 3 shows an examen of use in canopies on the pedestrian side with a two-use building.

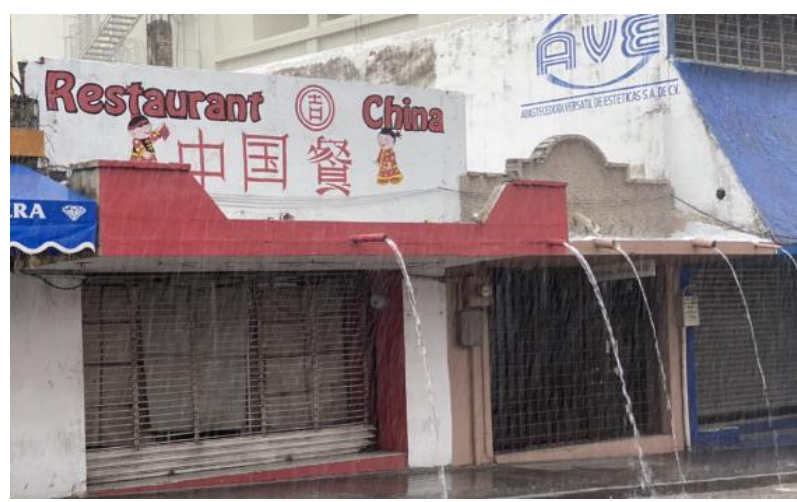

(a)

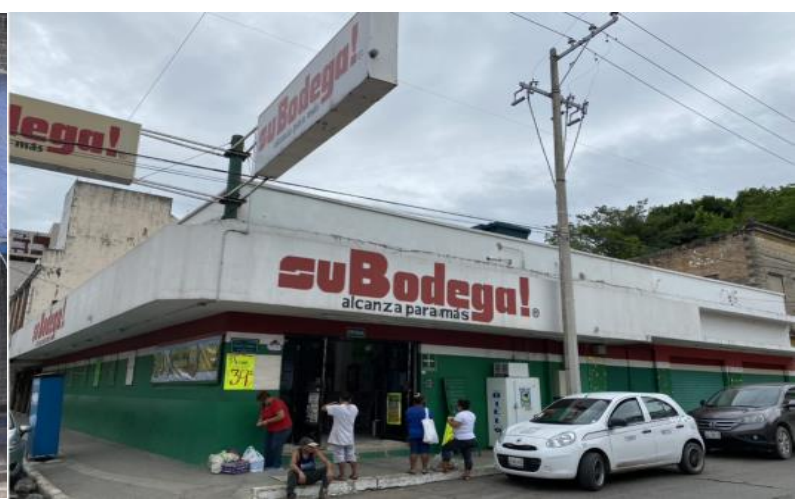

(b)

Figure 2. Use of canopies in facades for the main street in Tampico, Tamaulipas, for a) a familiar restaurant and b) local supermarket.

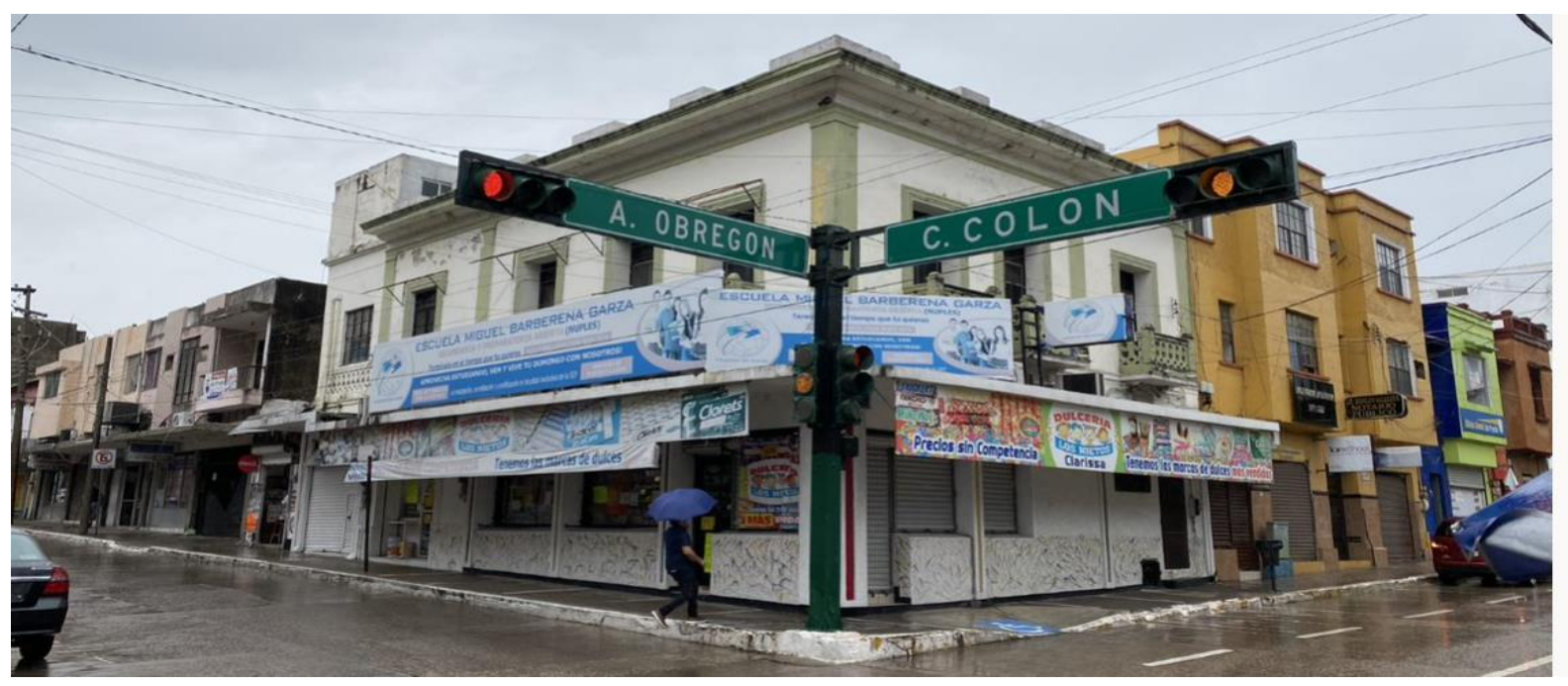

Figure 3. Use of existing lawn mowers in a building, where the 1 st floor is used for a candy store for parties and the 2 nd floor for a School 
Commercial graphic identification placed in front of the marquees maintains socio-cultural correspondence with pedestrians as the ambitious proposal for economic-political progress from the end of the 20th century in the 1990 s to the 21 st century. In this sense, socio-cultural, economic and political events, cultural hegemony, and socio-visual hegemony [5] impacted the city's stability and transformation. These characteristics substantially distinguished these delicate cultural designs. It was thus that the presence of identifying graphic design objects or identifying graphics located in the canopies that were found in historical and contemporary buildings are part of the visualization of the urban landscape, of the commercialization but also of the quality of life of the passerby local or visitor in the city. Precisely, the conditions in which they are exposed correspond to a fundamental factor for social security.

According to the UNESCO:

As expressed in current international charters and recommendations, current urban conservation policies have paved the way for safeguarding historic urban territories. However, current and future challenges require defining and implementing a new generation of public policies to identify and protect the historical stratification of cultural and natural values in urban environments [11].

About the urban image and the visual pollution of Tampico, the genuinely American supermarket model was adopted or tried to be simulated and not the European one; where the church or the unions did not participate economically as happened in Spain or Argentina (Raccanello, 2008, p. 81 [12]). That facilitated the development of the private initiative. According to Javier Moreno Lázaro (2012) in his article The Spanish and the Mexican commercial revolution: supermarket chains 1921-2011, national companies were vertically integrated and diversified commercial formats adjusted to foreign companies for mutual coexistence [13]. However, in Tampico, the commercial space was unequally shared and the temporal distance from the late twentieth century in the nineties with technological development, determined the socio-cultural model.

This model caused the articulation and displacement of textures, materials, and commercial languages in the urban context of Tampico, with the sensitive transformation of the landscape and transcultural and hegemonic identity. Thus, graphic design production in the facades' identification graphics became a space full of meanings, of socio-cultural and economic power that has remained historically.

In another aspect, historic buildings' preservation has focused on looking at the architectural heritage of historic buildings in the city center. A structured catalog was made on the Tamaulipas Government page with the legislated regulations for their protection. For example, in the document made by the H. Congress of Tamaulipas (1997) in the LVIII Legislature, called the Law of the Historical and Cultural Heritage of the State of Tamaulipas, which in its sixth chapter spoke of Protected Zones with historical and cultural significance (Decree 149, articles 25-32). The regulation for protecting heritage buildings, linked to political, social and cultural history, threatened by the installation of visual advertising elements was considered.

It is noted that only some regulations found for different purposes in the city mentioned aspects of commercial legibility on public roads: The Regulation for the Preservation of the Built Heritage of Tampico [14]. The city center's historical area was considered, but the rest of the areas also part of the urban image were excluded, with 66 blocks and 200 buildings, of which 190 were found in the heritage area. In this regulation, aspects of visibility were stipulated, such as regulations and control of mechanisms for visual contamination caused by advertisements, signs, commercial signs and facilities. It was determined that the authorization for provisions or modifications (exclusively) in the Historical Center, or assets attached to the historical-cultural heritage, were issued by the Department of Public Works of the $\mathrm{H}$. Ayuntamiento de Tampico. Figure 4 shows a modification in the façade that reduces people's possibility of considering a risk in security. 


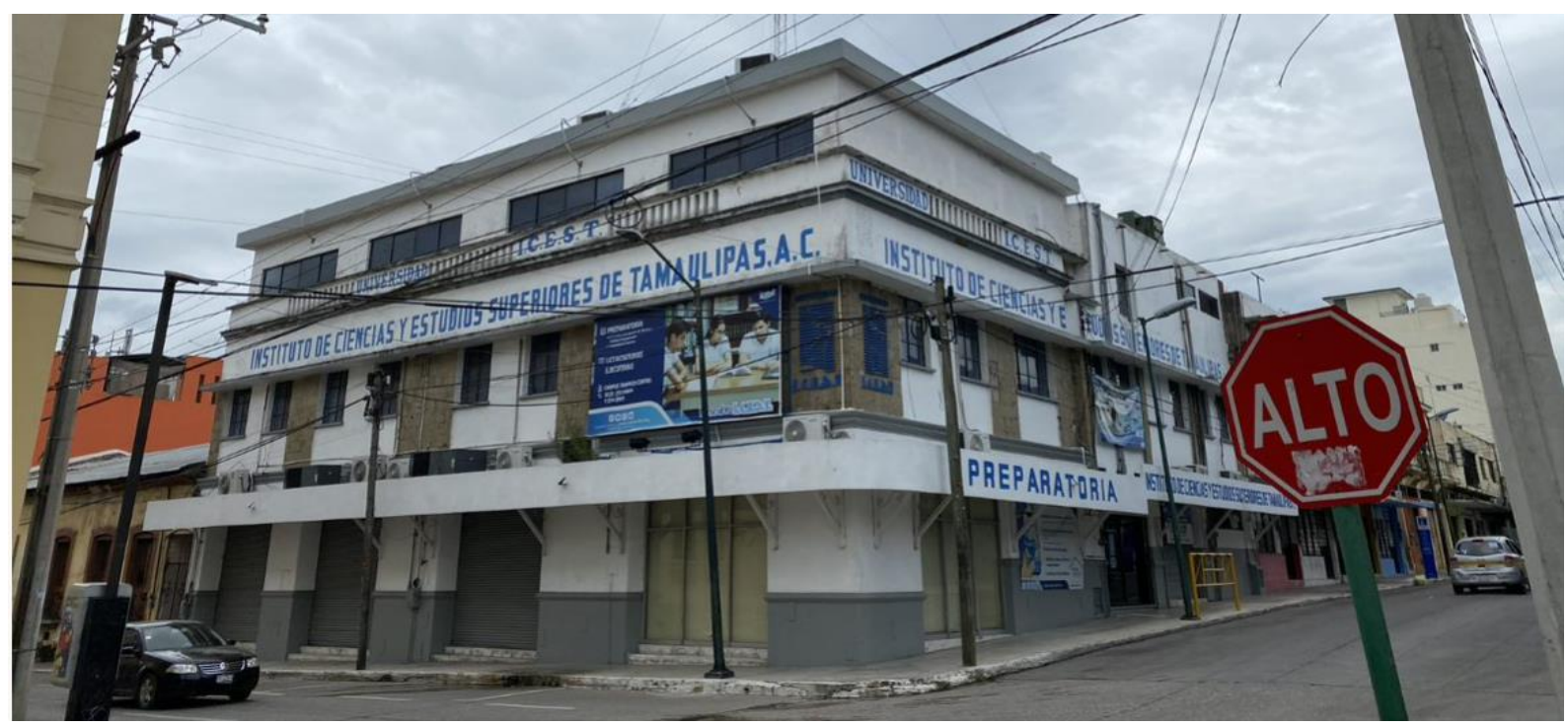

Figure 4. A building of flats used for high school

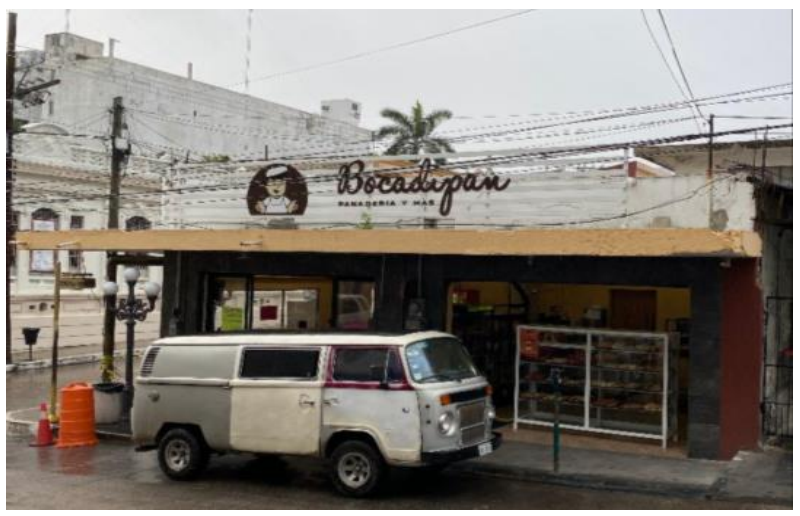

(a)

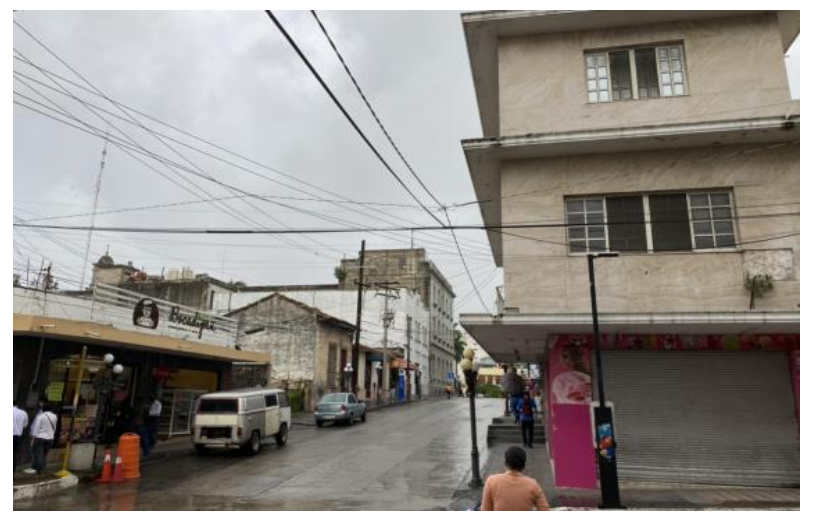

(b)

Figure 5. A building of flats used for bakery store in a) the front and b) lateral view

Commercial signs or identifying graphics were allowed with rectangular formats for the arched frames' straight ones and semicircular formats. Those, it was noted, should be placed on the ground floor of the upper part of the frame and the upper floor, in the lower third of the frame, in both cases with the Local Technical Committee's authorization.

The authorization contained a maximum of one advertisement per space, determining dimensions that were considered appropriate (in the case of several openings with color uniformity), exclusively with materials such as: wood, metal sheet, and wrought iron; with a maximum of two colors in a matte color tone. Materials were excluded (in normative theory but not in practice or execution): neon gas, flashing lights, lighting not incorporated into the advertisement, or placed indirectly. Commercial signs or identifying graphics placed outside the facades on public roads of the type: unipolar, bipolar, double or single billboard, electronic screen, sidewall or blanket, among others, were prohibited. Figure 5 shows a typical commerce-use as bakery store. In this case, the design promotes people's affluence on the sidewalk.

Today, according to commercial use, the historic buildings of Tampico articulate in their facades and the graphic design improvised implemented without a planned consideration by architects and designers as the same set materialized in the public thoroughfare [8]. Likewise, the aesthetics of the building with architectural qualities, style and history, among other aspects, were not considered.

Due to their geographical location, concrete buildings south of Tamaulipas are exposed to environmental loads, such as humidity, acid rain, and solar radiation [15-17].

Constructions' surface mainly receives the Exposed elements such as canopies. These subsystems are gradually affected without being sometimes noticeable until they present severe injuries. These loads cause potential damage that diminishes function, aesthetics, and safety as they support the identification graphics.

Finally, buildings are essential as heritage when it contributes to a cultural and historical state in that place. Furthermore, the Historic Center of Tampico had those 
crucial moments over time. Like the great oil boom in the Porfiriato stage, marking an entire historical-artistic era, which was reflected in its beautiful buildings.

\section{Conclusions}

Considering context with the dialectic of time produced the change of space, tradition, and modernization, represented graphically identifying and generating the hybridization (Canclini, 2004) built on the historic center's facades for commercial use. Social problems were part of the observational epistemological functioning represented graphically and materialized in the buildings. The architectural identifying graphic transformations and accumulations appeared as traces of materially represented cultural production.

It is emerging the consideration of the Strategic Plan of Government and Public Policies (2013-2016), Municipal Development Plan issued by the R. City Council of Tampico, in the technology and innovation section that indicates the objective of road signs. In this strategic section, technological tools for urban mobility and increased road safety must be reconsidered; environmental pollution; renovation and installation of informational service signs; among others. Public policies related to and considered in practice guarantee quality of life on public roads, with regulations for precision in commercial advertising, commercial signs, or identifying graphics. Another aspect to be considered an articulating element between competitiveness and well-being is protecting the environment with environmental awareness.

\section{Acknowledgments}

RILC and CEBR thank the UAT Project support 2021. LABG and KSD thank the CAEF PRODEP support 2021 IDCA 32211. The equipment used in this research were provided from FADU Research Centre and maintained by CONACYT Project No. 316443.

\section{REFERENCES}

[1] Durán, C. R. México: Desarrollo de Círculos Metropolitanos, Ciudades Interactivas y Futuro de Urbanización. "Desarrollo de los Círculos Metropolitanos y El Futuro de la Urbanización”, pp. 291. 2020.

[2] Murawski, S. A., Hollander, D. J., Gilbert, S., \& Gracia, A. "Producción de petróleo y gas en aguas profundas en el Golfo de México y tendencias globales relacionadas". In escenarios y respuestas a futuros derrames de petróleo profundo (pp. 16-32). Springer, Cham ed. 2020.

[3] Bartorila, M. Á., \& Cansino, R. I. L. "The Oil Industry and Modernity: Urban Transformations in Tampico-Madero,
Tamaulipas, Mexico". Contexto. Revista de la Facultad de Arquitectura de la Universidad Autonoma de Nuevo Leon, Vol. 11 No.14, 43-61. 2017. https://dialnet.unirioja.es/servl et/articulo?codigo $=6336514$

[4] Garcés Carrillo, J. D. C., \& Rosas Lusett, M. A. "Lógicas de inserción del urbanismo residencial cerrado al sur de Tamaulipas". Estudios demográficos y urbanos, Vol. 33, No. 3, pp. 639-669. 2018. http://dx.doi.org/10.24201/edu.v33i3.1795

[5] Lozano, R. Identification graphics on the facades of micro-businesses in Tampico. Cultural and communicational transformations due to commercial impact, 1994 to 2013 (PhD thesis). Universidad de Palermo, Buenos Aires, Argentina. 2018.

[6] Heidari Matin, N., \& Eydgahi, A. Factors affecting the design and development of responsive facades: a historical evolution. Intelligent buildings international, Vol. 12, No. 4, pp. 257-270. 2020. doi.org/10.1080/17508975.2018.15624 14

[7] Lane, J. F. "Pierre Bourdieu: A critical introduction". Pluto Press. 2000

[8] Lozano-Castro, R. I. \& Hernandez-Alvarado, A. "Dispute between architectural materiality and graphic image". Cuaderno Vol. 116, pp. 95. 2020.

[9] Lynch, K.. La imagen de la ciudad, (p. 11). España: Gustavo Gili. 2015

[10] Devalle, V. "The journey of form, emergence and consolidation of graphic design (1948-1984)", pp. 321-324. Buenos Aires, Argentina: Paidós. 2009

[11] UNESCO. A New International Instrument: The Proposed UNESCO Recommendation on the Historic Urban Landscape. 2010. http://whc.unesco.org/uploads/activities/ documents/activity-47-21.pdf24

[12] Lázaro, J. M.. Los españoles y la revolución comercial mexicana: las cadenas de supermercados, 1921-2011. Investigaciones de Historia Económica, Vol. 8, No. 2, pp. 69-82, 2012.

[13] Raccanello, M. "Before and after Wall-Mart, The history of the cooperative obrara de Bahía Blanca", p. 81. In XXI Jornadas de la Asociación Argentina de Historia Económica. Universidad Tres de Febrero, Buenos Aires. 2008.

[14] R. Ayuntamiento de Tampico. Reglamento para la preservación del Patrimonio Edificado de Tampico. Periódico Oficial número 120, 2-10. 2000 http://po.tamaulipas.gob.mx/wpcontent/uploads/2017/05/0 07 Tampico_Patrimonio_Edificado.pdf

[15] Gallegos-Villela, R. R., Larrea-Zambrano, F. D., Goyes-Lopez, C. E., Perez-Sanchez, J. F., Suarez-Dominguez, E. J., \& Palacio-Perez, A. Effect of natural additives on concrete mechanical properties. Cogent Engineering, Vol. 8, No. 1, pp. 1870790. 2021. https://doi.org/10.1080/23311916.2020.1870790.

[16] Aurora Martínez-Loaiza. María Teresa Sánchez-Medrano, "Variations in Mass and Resistance Due to Accelerated Weathering Effects in Concrete Specimens Used in Low-income Housing," Civil Engineering and Architecture, Vol. 8, No. 5, pp. 1039-1046, 2020. DOI: 10.13189/cea.2020.080530. 